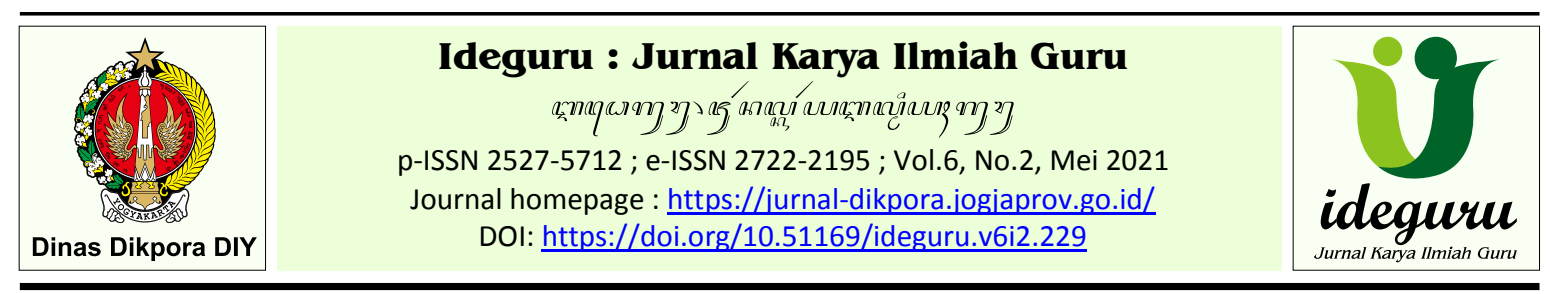

Artikel Penelitian - Naskah dikirim: 06/02/2021 - Selesai revisi: 27/03/2021 - Disetujui: 28/03/2021 - Diterbitkan: 01/05/2021

\title{
Peningkatan Self Leadership dalam Merencanakan Karir melalui Layanan Informasi Daring Model Cooperative Learning
}

\author{
Malthelda Yulianti \\ SMA Negeri 2 Yogyakarta \\ antin.yuli@gmail.com
}

\begin{abstract}
Abstrak: Penelitian tindakan kelas bimbingan konseling ini bertujuan untuk meningkatkan self leadership dalam merencanakan karir melalui layanan informasi daring model cooperative learning. Subyek penelitian adalah peserta didik kelas XII MIPA-1 SMA Negeri 2 Yogyakarta. Metode penelitian adalah observasi menggunakan instrumen yang disusun peneliti dengan mengacu pada kajian teori yang digunakan. Teknik analisis data menggunakan teknik deskriptif kualitatif, yakni mendeskripsikan pelaksanaan layanan informasi daring model cooperative learning dari tahap perencanaan, pelaksanaan tindakan, observasi dan refleksi pada setiap siklus. Data yang terkumpul dari instrumen penelitian pada siklus pertama, selanjutnya dibandingkan dengan data pada siklus kedua. Hasil penelitian menunjukan bahwa ada peningkatan kemampuan self leadership peserta didik, pada kategori aspek self awareness dari 75.88\% menjadi 84.38\% meningkat sebesar 7.50\%. Pada aspek self direct dari $78.12 \%$ menjadi $88.27 \%$ meningkat sebesar $10.60 \%$. Selanjutnya pada aspek self manage dari $76.56 \%$ menjadi $85.93 \%$ meningkat sebesar $9.37 \%$. Sedangkan pada aspek self accomplishment dari $78.11 \%$ menjadi $82.83 \%$ meningkat sebesar $4.72 \%$. Dari hasil penelitian tindakan kelas bimbingan konseling ini dapat disimpulkan bahwa layanan informasi daring model cooperative learning dapat meningkatkan self leadership dalam merencakanan karir peserta didik kelas XII MIPA-1 SMA Negeri 2 Yogyakarta.
\end{abstract}

Kata Kunci: self leadership, karir, layanan informasi daring.

\section{The Increase of Self Leadershif in Planning the Career by Online Model Cooperative Learning Information Service}

\begin{abstract}
This counseling guidance class action study aims to improve self leadership in planning career through online information servis of cooperative learning model. The subjects of the study were the students of class XII MIPA-1 SMA Negeri 2 Yogyakarta. The research method is observation using instruments compiled by researchers with reference to the theoretical studies used. Data analysis techniques use qualitative descriptive techniques, namely describing the implementation of online information services of coopr $\backslash$ erative learning model from the planning th stage, implementation of actions, observations and reflections on each cycle. The data collected from the research instruments in the first cycle were then compared with the data in the second cycle. The results study showed that there is an increase in the self leadership ability of learners, in the aspect category of the self awareness from $75.88 \%$ to $84.38 \%$ increased by $7.50 \%$. In terms of from $78.12 \%$ to $88.27 \%$ increased by $10.60 \%$. Furthermore the self management aspect from $76.56 \%$ to $85.93 \%$ increased by $9.37 \%$. While in the aspect of self accomplishment from $78.11 \%$ to $82.83 \%$ increased by $4.72 \%$. From the results of this counseling guidance class action research can be concluded that online information service of cooperative learning model can increase the self leadership in planning careers of students of class XII MIPA-1 SMA Negeri 2 Yogyakarta.
\end{abstract}

Keywords: self leadership, career, online information services 


\section{Pendahuluan}

Mengamati kondisi pembelajaran di sekolah saat ini, dalam masa darurat penyebaran Corona Virus Disease (COVID-19) ada perbedaan yang mendasar dalam proses pembelajaran di sekolah. Dalam masa darurat COVID-19 peserta didik tidak bisa bertatap muka langsung dengan guru, mereka mengikuti proses pembelajaran dari rumah masing-masing. Metode dan media pelaksanaan belajar dari rumah dilaksanakan dengan Pembelajaran Jarak Jauh (PJJ) yang dibagi dalam dua pendekatan, yaitu pembelajaran jarak jauh dalam jaringan (daring) dan pembelajaran jarak jauh luar jaringan (luring). Satuan pendidikan dapat memilih pendekatan daring atau luring atau kombinasi keduanya (SE Mendikbud No.15 Tahun 2020).

Sebelum masa darurat COVID-19 peserta didik merasa nyaman belajar di sekolah karena dapat bertemu dan berdiskusi dengan guru, serta dapat berinterasi langsung dengan temantemannya. Kondisi ini sesuai dengan makna pendidikan ditinjau dari sudut pandang psikososial yakni merupakan penumbuhkembangan sumber daya manusia melalui proses hubungan interpersonal yang berlangsung dalam lingkungan masyarakat yang terorganisasi (Syah, 2012: 36).

Dalam pembelajaran daring banyak kendala yang dialami peserta didik kelas XII MIPA-1 mereka mensharingkan: kesulitan menyelesaikan tugas-tugas yang banyak, kesulitan memahami dan mendalami layanan informasi yang disampaikan guru BK, serta merasa bingung dalam membuat keputusan karir setelah lulus dari SMA Negeri 2 Yogyakarta. Sebenarnya dalam pembelajaran daring saat ini justru dibutuhkan kesadaran, kemandirian dan tanggungjawab yang besar dalam belajar. Peserta didik memegang kendali utama dalam memimpin diri atau self leadership untuk mencapai tujuan belajarnya.

Peserta didik perlu dibimbing dengan layanan informasi agar dapat memahami potensi diri, cita-citanya, minat, harapan orang tua, kondisi sosial ekonomi keluarga, serta perlu dibimbing agar memiliki jiwa kepemimpinan, terutama menjadi leader diri sendiri atau self leadership supaya fokus pada pencapaian target belajarnya.

Self leadership merupakan kemampun mempengaruhi diri, membimbing diri, mengontrol dan mendorong diri sendiri, yang tercermin dalam pola pikir dan perilaku untuk menghasilkan kinerja yang lebih baik agar tujuan pribadinya tercapai (Neck dan Houghton dalam Ivantoro dan Barus, 2017).
Penerapan self leadership dapat membantu peserta didik mencapai tujuan belajarnya, yakni dapat diterima di jurusan dan PTN favorit atau Sekolah Kedinasan yang dicita-citakan. Hal ini selaras dengan tujuan bimbingan karir yakni membantu peserta didik mempunyai kemampuan menyelesaikan studinya, perkembangan karir, serta kehidupannya di masa depan (Kemendikbud, 2013).

Mengamati proses layanan informasi selama pembelajaran jarak jauh di kelas XII MIPA-1 masih ditemukan kecenderungan perilaku peserta didik yang mencerminkan self leadership rendah yakni: sebagian besar peserta didik terlambat bergabung di kelas BK, tidak segera mengumpulkan lembar refleksi, dan sebagian besar peserta didik kurang mampu memimpin diri untuk segera menyelesaikan tugas dengan berbagai alasan.

Kondisi tersebut menggambarkan keterlibatan peserta didik dalam layanan informasi belum optimal dan mendesak untuk segera diatasi, jika dibiarkan menyebabkan tujuan layanan informasi dan proses penanaman nilai-nilai tidak optimal. Dengan menerapkan nilai-nilai yang terkandung dalam self leadership sangat dimungkinkan peserta didik dapat merencanakan karirnya dengan baik. Karena self leadership adalah gabungan dari dua aspek yaitu: (1) aspek kognitif yaitu kegiatan yang dilaksanakan untuk mendorong peserta didik lebih termotivasi, (2) aspek perilaku merupakan proses kegiatan untuk mengontrol perilaku peserta didik agar selalu fokus pada tujuan yang akan dicapai (Neck dan Houghton, dalam Ivantoro dan Barus, 2017). Self leadership juga mengandung aspek: aspek self awareness, self direct, self manage, dan self accomplishment (Connor, dalam Fauziyah dan Ilyas, 2016).

Selain faktor-faktor tersebut diatas, beberapa hal yang mempengaruhi berhasil tidaknya layanan bimbingan konseling adalah faktor guru BK sebagai fasilitator, model dan media pembelajaran yang dipakai dalam menyampaikan layanan.

Upaya yang bisa dilakukan untuk mengatasi rendahnya self leadership peserta didik dengan menyelenggarakan kegiatan; 1) layanan orientasi, 2) kegiatan "Career Day", 3) layanan konseling individu, 4) layanan konseling kelompok, 5) layanan informasi materi self leadership dalam merencanakan karir dengan model pembelajaran menarik.

Model pembelajaran yang dapat diterapkan guru BK sangat beragam. Model pembelajaran adalah suatu pola atau langkah-langkah pembelajaran tertentu yang diterapkan sehingga 
tujuan yang diharapkan dapat tercapai dengan lebih efektif dan efisien (Amri, 2013: 7).

Untuk meningkatkan self leadership dalam merencanakan karir, peneliti memilih menggunakan layanan informasi model cooperative learning, karena menarik dan sesuai fitrah peserta didik sebagai makluk sosial yang tumbuh dan berkembang bersama orang lain, mempunyai tujuan dan tanggung jawab bersama. Dengan kenyataan tersebut, belajar berkelompok secara kooperatif akan melatih peserta didik untuk berbagi pengetahuan dan pengalaman hidup.

Layanan informasi daring model cooperative learning memungkinkan peserta didik semakin meningkat kemampuan self leadership dalam merencanakan karir, karena model cooperative learning memiliki beberapa kelebihan yakni: Meningkatkan harga diri tiap individu, adanya penerimaan terhadap perbedaan individu yang lebih besar sehingga konflik antar pribadi berkurang, sikap apatis berkurang, meningkatkan akal budi, kepekaan dan toleransi, meningkatkan kemajuan belajar, meningkatkan kehadiran, menambah motivasi dan percaya diri, menambah rasa senang di tempat belajar serta menyenangi teman-teman sekelasnya (Shoimin, 2017: 45).

Dalam Layanan informasi daring model cooperative learning akan membahas materimateri yang berkaitan dengan pemahaman diri: bakat, minat, cita-cita, memahami nilai-nilai dalam diri dan masyarakat, serta memahami berbagai jenis pekerjaan yang sesuai dengan potensi dirinya. Materi - materi tersebut sesuai dengan aspek-aspek yang dibahas dalam self leadership, sehingga dapat membantu peserta didik dalam membuat perencanaan karir yang sesuai dengan potensi dan kondisi dirinya. Karena hakekat layanan informasi adalah membimbing peserta didik dalam memahami informasi-informasi berkaitan potensi diri sendiri, permasalahan sosial, permasalahan belajar, pemilihan karir atau studi lanjut (Hasanah, 2012: 242).

Timbulnya berbagai permasalahan yang telah dipaparkan di atas, mendorong peneliti untuk mencari solusi dengan melakukan penelitian dengan judul " Peningkatan Self leadership Dalam Merencanakan Karir Melalui Layanan Informasi Daring Model Cooperative Learning Pada Peserta Didik Kelas XII MIPA-1 SMA Negeri 2 Yogyakarta".

Berdasarkan latar belakang yang dijelaskan di atas yang menjadi rumusan masalah dalam penelitian ini sebagai berikut: Apakah melalui layanan informasi daring model cooperative learning dapat meningkatkan self leadership dalam merencanakan karir pada peserta didik kelas XII MIPA-1 SMA Negeri 2 Yogyakarta? serta bagaimana penerapan layanan informasi daring model cooperative learning untuk meningkatkan self leadership dalam merencanakan karir pada peserta didik kelas XII MIPA-1 SMA Negeri 2 Yogyakarta?

Tujuan penelitian ini adalah untuk mengetahui peningkatkan self leadership dalam merencanakan karir melalui layanan informasi daring model cooperative learning pada peserta didik kelas XII MIPA-1 SMA Negeri 2 Yogyakarta; dan mengetahui penerapan layanan informasi daring model cooperatitive learning untuk meningkatkan self leadership dalam merencanakan karir peserta didik kelas XII MIPA1 setelah lulus SMA N 2 Yogyakarta.

Hasil penelitian ini diharapkan dapat memberikan manfaat bagi peserta didik dalam upaya meningkatkan kemampuan self leadership dalam merencanakan karirnya melalui layanan infomasi daring model cooperative learning yang diikuti; bagi Guru BK layanan informasi daring model cooperative learning dapat sebagai alternatif dalam membimbing peserta didik agar mempunyai kemampuan self leadership yang baik dalam membuat perencanaan karirnya; sedangkan bagi sekolah sebagai masukan dan bahan pertimbangan bahwa layanan informasi daring model cooperative learning bisa sebagai acuan dalam menanamkan nilai-nilai kemanusiaan, khususnya nilai self leadership dalam merencanakan karir peserta didik.

\section{Metode Penelitian}

Penelitian ini merupakan penelitian tindakan kelas bimbingan konseling, karakteristik prosedur penelitian yang digunakan menurut Stephen Kemmis Robin Mc Taggart (dalam Sukiman 2011: 138) yang dilaksanakan dalam dua siklus dan masing-masing siklus terdiri dari tahap perencanaan, tindakan, observasi, dan refleksi dalam satu spiral yang saling terkait. Menurut Warso (2018: 29) kekhasan dalam Penelitian Tindakan Kelas (PTK) adalah setiap siklusnya terdapat tahapan perencanaan, pelaksanaan, observasi dan refleksi.

Subjek dan tempat penelitian adalah peserta didik kelas XII MIPA-1 SMA Negeri 2 Yogyakarta. Pemilihan subyek penelitian berdasarkan permasalahan yang teridentifikasi pada saat pelaksanaan layanan informasi di kelas. Sumber data diperoleh dari seluruh peserta didik di kelas XII MIPA-1 SMA Negeri 2 Yogyakarta yang berjumlah 32 terdiri dari 11 laki-laki dan 21 perempuan. 
Pelaksanaan penelitian ini selama tiga bulan, bulan Juli dan bulan Agustus 2020 digunakan untuk penyusunan proposal dan instrumen penelitian, bulan September tahap pengambilan data siklus 1 dan siklus 2 (semester ganjil tahun pelajaran 2020/2021) serta penyusunan laporan hasil penelitian. Pengambilan data dilaksanakan dalam 4 kali tatap muka, setiap tatap muka selama 2 jam pelajaran daring $\mathrm{x} 45$ menit. Dalam melaksanakan penelitian, peneliti dibantu oleh seorang guru BK sebagai observer.

Penelitian ini dilaksanakan dalam dua siklus. Siklus 1 dilaksanakan untuk mengatasi rendahnya kemampuan self leadesrship dalam merencanakan karir. Siklus 2 dilaksankanan untuk menindaklanjuti hasil refleksi tindakan pada siklus 1 , sehingga setelah akhir siklus 2 diharapkan kemampuan self leadership peserta didik dalam merencanakan karir meningkat. Maka disusunlah kerangka pikir penelitian seperti dalam gambar 1 berikut ini:

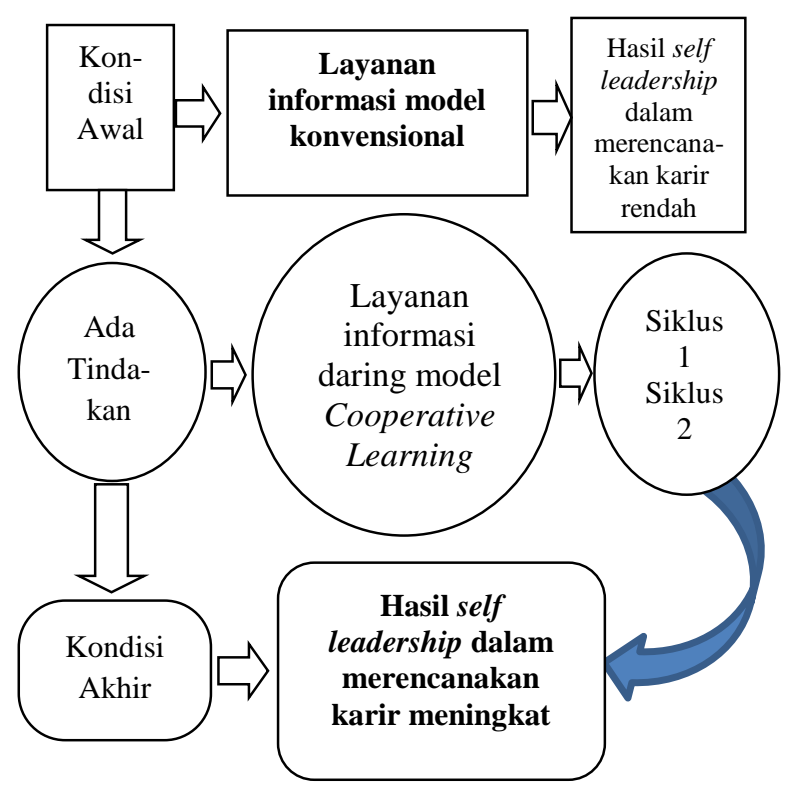

Gambar 1. Kerangka pikir layananan informasi daring model cooperative learning

Berdasarkan kerangka pikir di atas maka hipotesis tindakan sebagai berikut: Penerapan layanan informasi daring model cooperative learning dapat meningkatkan self leadership dalam merencanakan karir peserta didik kelas XII MIPA-1 SMA Negeri 2 Yogyakarta.

\section{Tahapan tindakan siklus 1}

Tahap perencanaan guru BK: menyusun RPL BK sesuai sintak cooperative learning, menyusun instrument observasi, mengunggah presensi, pretest, materi self leadesrship (ppt), LKPD aspek self leadership, lembar kerja kelompok (LKK) dan post-test, menginformasikan kode akses kelas BK dan link untuk google meeting di grup kelas.

Tahap melaksanakan tindakan pada pertemuan 1, dilaksanakan secara daring pada hari Jumat, 11 September 2020 selama 2 jam pelajaran malalui aplikasi google classroom diawali dengan google meeting, dengan indikator kompetensi dasar bimbingan menanamkan konsep self leadership dan aspek-aspeknya. Peserta didik diarahkan mendalami konsep aspek-aspek dalam self leadership, mengerjakan LKPD, serta dipahamkan cara kerja di kelompok daring yang efektif.

Pertemuan 2 dilaksanakan secara daring pada hari Jumat, 18 September 2020 melalui aplikasi goolge classroom, diawali dengan google meeting. Indikator kompetensi bimbingan yakni analisis potensi diri berdasarkan aspek-aspek self leadership untuk membuat perencanaan karir.

Peserta didik diarahkan untuk membuat perencanaan karir berdasarkan analisis aspekaspek self leadership dalam LKPD, mengerjakan instrument post-test, dan guru BK memberi penghargaan peserta didik yang hasil kinerjanya bagus.

Tahapan penelitian berikutnya adalah observasi, dilakukan dengan mengamati aktivitas guru dalam menyampaikan layanan informasi model cooperative learning dengan menggunakan instrumen aktivitas guru BK, dan mengamati aktivitas peserta didik dalam mengikuti layanan informasi model cooperative learning dengan menggunakan instrument aktivitas peserta didik. Respon peserta didik diamati menggunakan instrument respon peserta didik.

Tahapan refleksi dilakukan dengan cara mencermati hasil dari tindakan siklus 1 dan hasil diskusi dengan observer. Jika ditemukan hal-hal yang harus diperbaiki, maka guru BK menyusun kembali rencana layanan informasi model cooperative learning yang akan dilakukan pada siklus 2 dengan memperhatikan masukan observer.

\section{Tahapan Tindakan siklus 2}

Siklus 2 dilaksanakan dengan tahapan yang sama seperti siklus 1 dengan melakukan beberapa tindakan perbaikan. Tahap perencanaan; guru BK menyusun RPL-BK berdasarkan hasil refleksi pada siklus 1, mengunggah materi self leadesrship (ppt) dan video, LKPD self leadership, lembar kerja kelompok (LKK), jadual video call dan post-test.

Tahapan tindakan pertemuan 3 dilaksanakan secara daring pada hari Kamis, 24 September 2020 selama 2 jam pelajaran melalui aplikasi google classroom dan video call memakai 
WhatsApp group, kelompok diskusi menggunakan kelompok yang sudah terbentuk sejak awal. Indikator kompetensi dasar bimbingan yakni analisis jurusan yang dipilih di PTN. Kegiatan layanan informasi dilakukan dengan sintak cooperative learning. Peserta didik dibimbing untuk menganalisis jurusan yang diminati di PTN dalam LKPD, Kelompok memilih waktu video call durasi 15 menit yang diunggah di google classroom. Pelaksanaan video call 3 jadwal di dalam jam BK dan 7 jadwal diluar jam BK.

Tahap tindakan pertemuan 4 dilaksanakan secara daring pada hari jumat 25 September 2020 selama 2 jam pelajaran, Waktu video call tiap kelompok selama 30 menit. Kelompok dapat memilih jadwal video call di google classroom; 2 jadwal di dalam kelas BK dan 8 jadwal dilaksanakan hari Sabtu 26 September 2020. Indikator kompetensi dasar bimbingan membahas hambatan diterima di PTN favorit dan upaya mengatasinya. Peserta didik dibimbing untuk merefleksikan hambatan dan usaha-usaha yang dilakukan agar diterima di PTN favorit.

Tahap penelitian berikutnya adalah observasi, dilakukan dengan cara melakukan pengamatan aktivitas guru BK dalam menyampaikan layanan informasi model cooperative learning, diamati menggunakan instrumen aktivitas guru BK, Pengamatan aktivitas peserta didik selama mengikuti layanan informasi model cooperative learning menggunakan instrumen perilaku peserta didik. Selanjunya pengamatan tentang respon peserta didik dilaksanakan menggunakan instrument respon peserta didik, dan untuk mengamati hasil self leadership menggunakan instrument post-test.

Tahapan refleksi siklus 2 adalah kegiatan ini dilaksanakan untuk memperbaiki tindakantindakan yang telah direncanakan sebelumnya. Refleksi pada tahap ini dilaksanakan secara menyeluruh bertujuan untuk mengevaluasi hasil tindakan yang telah dilaksanakan, apakah secara konsisten sudah dapat mencapai tujuan penelitian yang telah dirumuskan yaitu meningkatkan self leadership dalam merencanakan karir.

\section{Jenis Data, Instrumen dan Teknik Analisa Data}

Data yang diperlukan dalam penelitian ini adalah data aktivitas guru dalam melaksanakan layanan informasi daring model cooperative learning, data aktivitas peserta didik dalam mengikuti layanan informasi daring model cooperative learning, data respon peserta didik terhadap layanan informasi yang disampaikan, dan data kemampuan self leadership peserta didik dalam merencanakan karir.
Data keterlaksanaan layanan informasi daring model cooperative learning diperoleh melalui observasi menggunakan instrument aktivitas guru BK dan instrument aktivitas peserta didik, serta dilengkapi dengan dokumen tangkapan layar (screenshot) dari aplikasi pembelajaran daring sesuai sintak cooperative learning. Untuk mengetahui respon peserta didik diobservasi menggunakan teknik non test dengan menggunakan instrument respon peserta didik. Selanjutnya data kemampuan self leadership dalam merencanakan karir peserta didik, diobservasi dengan teknik tes tertulis dengan menggunakan instrumen pre-test dan post-test yang disusun menggunakan skala likert. Dalam skala likert variabel yang akan diukur dijabarkan menjadi indikator variabel yang dijadikan titik tolak menyusun butir-butir instrumen berupa pernyataan-pernyataan yang harus dijawab responden (Widoyoko, 2018: 104).

Indikator variabel penelitian ini adalah diakhir siklus terdapat peningkatan self leardershif dalam merencanakan karir peserta didik. Kriteria peningkatannya yaitu: 1) $80 \%$ Peserta didik mempunyai kesadaran diri (self awareness) yang baik untuk memperbaiki kinerja. 2) $80 \%$ Peserta didik mampu mengarahkan diri (self direct) ke arah cita-cita yang akan diraih. 3) $80 \%$ Peserta didik mampu mengelola diri (self manage) dengan menyusun kegiatan-kegiatan berdasarkan priotitas. 4) $80 \%$ Peserta didik mempunyai penyelesaian diri (self accomplishmnt) yang baik, untuk melaksanakan perencanaan yang disusun.

Teknik analisa data yang dipakai adalah teknik diskriptif; yakni penelitian yang berusaha menggambarkan suatu fenomena, peristiwa, gejala, baik menggunakan data kualitatif maupun kuantitatif (Sugiono, 2014: 336). Teknik diskriptif berusaha menggambarkan obyek atau subyek yang diteliti sesuai dengan apa adanya (Sukardi, 2014: 163).

Tekhnik deskriptif kualitatif digunakan untuk mendiskripsikan data pelaksanaan layanan informasi daring model cooperative learning mulai tahap perencanaan, pelaksanaan, observasi dan refleksi dari siklus 1 dan siklus 2. Digunakan pula untuk mendiskripsikan data keaktifan peserta didik dalam mengikuti layanan dan mendiskripsikan data respon peserta didik.

Teknik analisa data diskriptif kuantitatif digunakan untuk mendiskripsikan hasil tindakan yang mengacu pada tujuan penelitian yakni meningkatnya self leadership dalam merencanakan karir, dengan cara menganalisis data pre-test, data post-test siklus 1 dan data posttest siklus 2 dengan memperhatikan indikator 
keberhasilan penelitian yang telah ditetapkan. Hasil tindakan dikategorikan meningkat jika ada progres ke arah lebih baik dari data pre-test jika dibandingkan dengan data post-test siklus 1 , dan data post-test siklus 2 , serta minimal sama atau lebih besar dari ketetapkan yakni $80 \%$.

\section{Hasil dan Pembahasan}

Hasil observasi aktivitas guru BK dalam melaksanakan layanan informasi daring model cooperative learning dari 16 aspek yang dinilai pada siklus 1 guru BK sudah melaksanakan layanan kategori baik 13 aspek, kategori cukup 3 aspek. Pada siklus 2 guru BK sudah melaksanakan layanan kategori baik 15 aspek dan kategori cukup 1 aspek. Untuk melihat persentase peningkatan aktivitas guru BK bisa dilihat pada tabel 1 berikut.

Tabel 1. Aktivitas guru BK dalam melaksanakan layanan informasi model cooperative learning siklus 1 dan 2 .

\begin{tabular}{clcc}
\hline No & Kategori & \multicolumn{2}{c}{ Persentase } \\
& & Siklus 1 & Siklus 2 \\
\hline 1. & Baik & $81,25 \%$ & $93,75 \%$ \\
2. & Cukup & $18,75 \%$ & $6,25 \%$ \\
3. & Kurang & $0 \%$ & $0 \%$ \\
\hline
\end{tabular}

Berdasarkan data dalam tabel 1 ada tindakan perbaikan yang dilakukan guru BK setelah siklus 1, dilakukan sesuai dengan masukan dan hasil refleksi bersama observer, yakni tahap menyajikan informasi dilengkapi video motivasi, dalam menggorganisir dan membimbing kelompok dilakukan melalui video call. Tindakan kategori baik siklus 1 sebesar $81,25 \%$ pada siklus 2 menjadi $93,74 \%$, meningkat $12,49 \%$.

Kemudian data hasil aktivitas peserta didik didalam mengikuti layananan informasi daring model cooperative learning, dari 16 aspek peserta didik melakukan aktivitas kategori baik 12 dan kategori cukup 4. Pada siklus 2 dari 16 aspek, aktivitas peserta didik kategori baik 15 dan kategori cukup 1. Untuk persentase peningkatannya dapat dilihat pada tabel 2 berikut.

Tabel 2. Aktivitas peserta didik dalam melaksanakan layanan informasi model cooperative learning siklus 1 dan 2 .

\begin{tabular}{clcc}
\hline No & Kategori & \multicolumn{2}{c}{ Persentase } \\
& & Siklus 1 & Siklus 2 \\
\hline 1. & Baik & $75 \%$ & $93,75 \%$ \\
2. & Cukup & $25 \%$ & $6,25 \%$ \\
3. & Kurang & $0 \%$ & $0 \%$ \\
\hline
\end{tabular}

Dari data tabel 2 di atas, ada perbaikan aktivitas peserta didik dalam mengikuti layanan pada siklus 2, hal ini dikarenakan pada siklus 1 peserta didik baru pertama kali bekerja dalam kelompok daring. Maka pada siklus 2 dengan memperhatikan masukan dan hasil diskusi dengan observer, pada tahap menyajikan informasi dilengkapi video motivasi, sehingga peserta didik mendapat inspirasi dari tokohtokoh yang berhasil mencapai cita-citanya. Dalam diskusi kelompok menggunakan aplikasi video call sehingga semua anggota hadir, saling menyapa, senang bisa melihat wajah temantemannya, semua anggota berpartisipasi menyampaikan pendapatnya, suasana diskusi menjadi menyenangkan karena peserta didik merasa diterima dan mengalami permasalahan yang kurang lebih sama dengan temantemannya. Hal ini sesuai dengan pendapat Shoimin (2017: 45) yang menyatakan model cooperative learning dapat meningkatkan kehadiran, menambah motivasi dan percaya diri, menambah rasa senang di tempat belajar serta menyenangi teman-teman sekelasnya.

Untuk mengetahui hasil dari self leadership peserta didik dalam merencanakan karir, dapat dilakukan dengan membandingkan hasil self leadership dari sebelum dilakukan tindakan atau pre test kemudian dibandingkan dengan hasil setelah dilakukan tindakan atau post-test siklus 1 , yang digolongkan menjadiempat aspek yaitu: aspek self awareness, aspek self direct, aspek self manage dan aspek self accomplishment seperti tampak pada tabel 3 berikut.

Tabel 3. Perbandingan hasil Self Leadership Dalam Merencanakan Karir siklus 1

\begin{tabular}{|c|c|c|c|c|c|}
\hline \multirow{4}{*}{$\begin{array}{l}\text { Aspek } \\
\text { Self } \\
\text { Awareness }\end{array}$} & \multicolumn{4}{|c|}{ Persentase Rekap Jawaban } & \multirow[t]{2}{*}{ Ket } \\
\hline & Selalu & Sering & Jarang & $\begin{array}{c}\text { Tidak } \\
\text { Pernah }\end{array}$ & \\
\hline & 31.25 & 26.88 & 32.50 & 9.38 & Pre-test \\
\hline & 44.38 & 32.50 & 18.13 & 5 & Post-test \\
\hline \multirow{4}{*}{$\begin{array}{l}\text { Aspek } \\
\text { Self Direct }\end{array}$} & \multicolumn{4}{|c|}{ Persentase Rekap Jawaban } & \multirow[t]{2}{*}{ Ket } \\
\hline & Selalu & Sering & Jarang & $\begin{array}{c}\text { Tidak } \\
\text { Pernah }\end{array}$ & \\
\hline & 38.28 & 29.69 & 20.31 & 11.72 & Pre-test \\
\hline & 53.13 & 31.25 & 11.71 & 3.90 & Post-test \\
\hline \multirow{4}{*}{$\begin{array}{l}\text { Aspek } \\
\text { Self } \\
\text { Manage }\end{array}$} & \multicolumn{4}{|c|}{ Persentase Rekap Jawaban } & \multirow[t]{2}{*}{ Ket } \\
\hline & Selalu & Sering & Jarang & $\begin{array}{c}\text { Tidak } \\
\text { Pernah }\end{array}$ & \\
\hline & 34.38 & 26.60 & 26.60 & 12.50 & Pre-test \\
\hline & 50 & 31.25 & 15.62 & 3.13 & Post-test \\
\hline \multirow{4}{*}{$\begin{array}{l}\text { Aspek } \\
\text { Self } \\
\text { accomplish } \\
\text { ment }\end{array}$} & \multicolumn{4}{|c|}{ Persentase Rekap Jawaban } & Ket \\
\hline & Selalu & Sering & Jarang & $\begin{array}{c}\text { Tidak } \\
\text { Pernah }\end{array}$ & \\
\hline & 34.38 & 29.69 & 18.75 & 17.28 & Pre-test \\
\hline & 51.56 & 31.25 & 14.06 & 3.13 & Post-test \\
\hline
\end{tabular}


Dari data tabel 3 tersebut, self leadership peserta didik dikategorikan tinggi jika skor perolehannya minimal sering melakukan atau selalu melakukan. Dari jawaban sering melakukan dan selalu melakukan ada peningkatan hasil dari sebelum tindakan dengan sesudah tindakan. Pada aspek self awareness sebelum tindakan $58.13 \%$ setelah tindakan siklus 1 menjadi $76.88 \%$, meningkat $18.75 \%$. Hal ini menunjukkan bahwa kesadaran diri dapat dijadikan dasar memperbaiki kinerja maupun meningkatkan kepercayaan diri dalam mewujudkan cita-citanya (Neck dan Houghton dalam Ivantoro dan Barus, 2017).

Pada aspek self direct data sebelum tindakan $67.97 \%$ setelah tindakan siklus 1 menjadi $78.12 \%$, aspek self direct meningkat $10.15 \%$. Aspek self manage data sebelum tindakan 60,98\% setelah tindakan siklus 1 menjadi 76.56\%, aspek self manage meningkat $15.58 \%$. Aspek self accomplishment sebelum tindakan $64.07 \%$ setelah siklus 1 menjadi $78.11 \%$, aspek self accomplishment meningkat $14.04 \%$.

Dari pemaparan di atas, semua kategori aspek self leadership mengalami peningkatan, namun belum mencapai batas minimal indikator keberhasilan yakni $80 \%$. Maka perlu melakukan perencanaan dan tindakan yang lebih baik lagi pada siklus 2 sesuai masukan dan hasil refleksi observer.

Tabel 4. Hasil Self Leadership Siklus 1 dan 2

\begin{tabular}{|c|c|c|c|c|c|}
\hline \multirow{5}{*}{$\begin{array}{l}\text { Aspek } \\
\text { Self } \\
\text { Awareness }\end{array}$} & \multicolumn{4}{|c|}{ Persentase Rekap Jawaban } & \multirow{2}{*}{$\begin{array}{c}\text { Ket. } \\
\text { Post- } \\
\text { test }\end{array}$} \\
\hline & Selalu & Sering & Jarang & $\begin{array}{l}\text { Tidak } \\
\text { Pernah }\end{array}$ & \\
\hline & & & & & Siklus \\
\hline & 44.38 & 32.50 & 18.13 & 5 & 1 \\
\hline & 53.75 & 30.63 & 11.88 & 1.88 & $\begin{array}{c}\text { Siklus } \\
2\end{array}$ \\
\hline \multirow{5}{*}{$\begin{array}{l}\text { Aspek } \\
\text { Self Direct }\end{array}$} & \multicolumn{4}{|c|}{ Persentase Rekap Jawaban } & Ket. \\
\hline & Selalu & Sering & Jarang & $\begin{array}{l}\text { Tidak } \\
\text { Pernah }\end{array}$ & $\begin{array}{c}\text { Post- } \\
\text { test }\end{array}$ \\
\hline & & & & & Siklus \\
\hline & 46.87 & 31.25 & 17.96 & 4.69 & 1 \\
\hline & 58.59 & 29.68 & 11.72 & 0.78 & $\begin{array}{c}\text { Siklus } \\
2\end{array}$ \\
\hline \multirow{4}{*}{$\begin{array}{l}\text { Aspek } \\
\text { Self Manage }\end{array}$} & \multicolumn{4}{|c|}{ Persentase Rekap Jawaban } & Ket. \\
\hline & Selalu & Sering & Jarang & $\begin{array}{l}\text { Tidak } \\
\text { Pernah }\end{array}$ & $\begin{array}{c}\text { Post- } \\
\text { test }\end{array}$ \\
\hline & 45.31 & 31.25 & 19.53 & 3.90 & $\begin{array}{c}\text { Siklus } \\
1\end{array}$ \\
\hline & 57.03 & 28.90 & 14.06 & 0 & $\begin{array}{c}\text { Siklus } \\
2\end{array}$ \\
\hline \multirow{5}{*}{$\begin{array}{l}\text { Aspek } \\
\text { Self } \\
\text { Accomplish } \\
\text { ment }\end{array}$} & \multicolumn{4}{|c|}{ Persentase Rekap Jawaban } & Ket. \\
\hline & Selalu & Sering & Jarang & $\begin{array}{l}\text { Tidak } \\
\text { Pernah }\end{array}$ & $\begin{array}{c}\text { Post- } \\
\text { test }\end{array}$ \\
\hline & 42.18 & 35.93 & 18.75 & 3.13 & $\begin{array}{c}\text { Siklus } \\
1\end{array}$ \\
\hline & & & & & Siklus \\
\hline & 59.38 & 23.44 & 15.63 & 1.56 & 2 \\
\hline
\end{tabular}

Hasil dari self leadership dalam merencanakan karir dapat dilihat dengan membandingkan hasil siklus 1 dengan hasil siklus 2 seperti tersaji pada tabel 4 .

Mencermati data pada tabel 4, tampak ada peningkatan hasil dari siklus 1 dan siklus 2. Aspek self awareness peserta didik, siklus 1 pada posisi $76.88 \%$, setelah tindakan siklus 2 mencapai $84.38 \%$. Jika dikaitkan indikator keberhasilan meningkat sebesar 7.50\%.

Pada aspek self direct pada siklus 1 sebesar $78.12 \%$, setelah siklus 2 mencapai $88.27 \%$, meningkat sebesar $10.60 \%$. Aspek self manage sikus 1 sebesar $76.56 \%$, setelah tindakan siklus 2 menjadi $85.93 \%$ peningkatan aspek self manage sebesar 9.37\%. Aspek self accomplishment siklus 1 mencapai $78.11 \%$, setelah tindakan siklus 2 menjadi $82.83 \%$, meningkat sebesar $4.72 \%$.

Dari penjelasan di atas diperoleh gambaran bahwa semua aspek self leadership dalam merencanakan karir mengalami peningkatan, dan sudah memenui indikator keberhasilan yang ditetapkan dalam penelitian ini yakni $80 \%$. Pencapaian indikator terbesar pada aspek self direct yakni 88, 27\%. Kemampuan peserta didik mengarahkan diri pada tujuan sangat penting.

Menurut Robbins kemampuan self leadership mendorong peserta didik lebih bertanggunjawab dan mampu mengendalikan perilakunya sendiri kearah pencapaian tujuan (dalam Fuziyah dan Ilyas, 2016: 493).

Penelitian lain yang berjudul "Peningkatan Karakter Self leadership melalui layanan Bimbingan Klasikal dengan Pendekatan Experiential Learning" menunjukan bahwa berdasarkan hasil Tes Karakter Self Leadership terdapat peningkatan karakter self leadership antara sebelum dan sesudah tindakan; berdasarkan hasil Self Assesment Scale Karakter Self Leadership terdapat peningkatan karakter self leadership antar siklus; ada peningkatan karakter self leadership yang signifikan antara sebelum dan sesudah tindakan $(\mathrm{pv}=0,001)$ dan antarsiklus $(\mathrm{pv}=0,000)$; menurut siswa model ini sangat efektif meningkatan karakter self leadership (Ivantoro dan Barus, 2017: 29 - 48).

Hal ini menguatkan bahwa memahami dan menerapkan aspek-aspek self leadesrship dalam merencanakan karir sangat penting, karena tujuan utama peserta didik setelah lulus SMA yakni dapat melanjutkan studi di jurusan dan di PTN yang dicita-citakan, peranan self leadership memberi arah atau pedoman bagaimana tahapan dan upaya-upaya yang harus dilakukan untuk mewujudkan cita-citanya tersebut. 


\section{Simpulan dan Saran}

Berdasarkan hasil penelitian tindakan kelas bimbingan konseling yang sudah dilaksanakan maka dapat disimpulkan bahwa hasil dari penerapan layanan informasi daring model cooperative learning dapat meningkatkan self leadership dalam merencanakan karir peserta didik pada kelas XII MIPA-1 SMA Negeri 2 Yogyakarta Tahun Ajaran 2020/2021.

Setelah proses pelaksanaan siklus 2 pemahaman aspek-aspek self leadership dalam merencanakan karir meningkat; aspek self awareness hasil siklus 1 sebesar $76.88 \%$ dan setelah dilakukan tindakan siklus 2 mencapai 84.38\% meningkat sebesar 7.50\%.

Pada kategori aspek self direct hasil siklus 1 memperoleh $78.12 \%$, setelah tindakan siklus 2 menjadi $88.27 \%$, peningkatan aspek self direct sebesar $10.15 \%$. Selanjutnya pada aspek self manage hasil tindakan siklus 1 sebesar $76.56 \%$ setelah selesai tindakan siklus 2 menjadi $85.93 \%$ meningkat sebesar $9.37 \%$. Aspek self accomplishment hasil pada siklus 1 sebesar $78.11 \%$, setelah siklus 2 menjadi $82.83 \%$ meningkat sebesar $4.72 \%$.

Berdasarkan hasil pengamatan observer dan dipadukan dengan instrumen respon peserta didik dalam mengikuti layanan informasi daring model cooperative learning setelah tindakan siklus 2, dari 15 pertanyaan terdapat 9 pertanyaan yang skornya diatas $90 \%$ yaitu: Memahami potensi diri sebesar 96\%. Memahami tujuan belajar 93.75\%. Berani mengemukakan pendapat 93.75\%. Lebih akrab dengan teman sebesar 90.62\%. Menghargai pendapat orang lain $90.62 \%$. Mudah dalam memahami materi sebesar 93.75\%. Diterima oleh teman-teman dalam kelompok 93.75\%. Mempunyai pemahaman yang lebih baik dalam memilih jurusan di Perguruan Tinggi sebesar 96.88\%. Dan merasakan suasana persaudaraan di kelas $90.62 \%$.

Dari perolehan data tersebut dapat disimpulkan bahwa hipotesa tindakan yang diajukan peneliti dapat terbukti, bahwa layanan informasi daring model cooperative learning dapat meningkatkan self leadership peserta didik kelas XII MIPA -1 SMA Negeri 2 Yogyakarta.

Berdasarkan hasil penelitian tindakan kelas bimbingan konseling peningkatan self leadership dalam merencanakan karir melalui layanan informasi daring model cooperative learning, peneliti sarankan untuk diadakan penelitian dengan model pembelajaran lain sebagai alternatif untuk meningkatkan self leadership peserta didik. Pentingnya peneliti memahami perkembangan psikologi peserta didik dalam penanaman nilai-nilai self leadership. Untuk menanamkan self leadership sebagai budaya hidup, peserta didik perlu dibimbing dan perlu dipantau terus-menerus agar nilai self leadership sungguh-sungguh menjadi budaya hidup yang akan diterapkan peserta didik dimanapun dia berada.

\section{Daftar Pustaka}

Amri, S. (2013). Pengembangan dan Model Pembelajaran Dalam Kurikulum 2013. Jakarta: Prestasi Pustaka.

Fauziyah. U dan Ilyas. M. (2016). Self Leadership Dan Prokrastinasi Akademik Mahasiswa STKIP PGRI Sumenep. Jurnal Inovasi Pendidikan Di Era Big Data dan Aspek Psikologinya, 491-499. diakses dari http://digilib.mercubuana.ac.id/manager/t !@file_artikel_abstrak/Isi_Artikel_7278809 83851.pdf

Hasanah, A. 2012. Pengembangan Profesi Guru. Bandung: Pustaka Setia.

Ivantoro. D dan Barus. G. (2017). Peningkatan Karakter Self Leadership Melalui Layanan Bimbingan Klasikal Dengan Pendekatan Experiential Learning Pada Siswa Kelas VIII A SMP BOPKRI 1 Yogyakarta Tahun Ajaran 2015/2016. Jurnal Ilmiah Implementasi Kurikulum BK, 29-48. Diakses dari http://journal2.um.ac.id/index.php/sembk /article/view/1270

Kememdikbud. (2020). Surat Edaran NOMOR: 15 Tahun 2020 tentang Pedoman Penyelenggaraan Belajar dari Rumah Dalam Masa Darurat Penyebaran Corona Virus Disease. Jakarta: Kemendikbud.

Kemendikbud. (2013). Implementasi Kurikulum 2013 bagi Guru Bimbingan Konseling. Jakarta: Kemendikbud.

Sukardi. (2014). Metodologi Penelitian Pendidikan. Jakarta: Bumi Aksara.

Sugiyono. (2014). Cara Mudah Menyusun Skripsi, Tesis, dan Disertasi. Bandung; Alfabeta.

Shoimin, A. (2013). Model Pembelajaran Inovatif. Yogyakarta: Ar-Ruzz Media.

Syah, M.(2012). Psikologi Belajar. Jakarta: Rajagrafindo Persada.

Sukiman. (2011). Penelitian Tindakan Kelas Untuk Guru Pembimbing. Yogyakarta: Paramitra.

Warso, A. (2018). Penelitian Tindakan Kelas.Yogyakarta: Graha Cendekia.

Widoyoko, E. (2018) Teknik Penyusunan Instrumen Penelitian. Yogyakarta: Pustaka Belajar. 